ISSN 0854-9818

OCCASIONAL PAPER NO. 30

June 2000

\title{
The Underlying Causes of Forest Decline
}

\section{Arnoldo Contreras-Hermosilla}

CENTER FOR INTERNATIONAL FORESTRY RESEARCH

Office address: Jalan CIFOR, Situ Gede, Sindang Barang, Bogor 16680, Indonesia Mailing address: P.O. Box 6596 JKPWB, Jakarta 10065, Indonesia

Tel.: +62 (251) 622622; Fax: +62 (251) 622100

E-mail: cifor@cgiar.org

Website: http://www.cifor.cgiar.org 


\section{The CGIAR System}

The Consultative Group on International Agricultural Research (CGIAR) is an informal association of 41 public and private sector donors that supports a network of sixteen international agricultural research institutes, CIFOR being the newest of these. The Group was established in 1971. The CGIAR Centers are part of a global agricultural research system which endeavours to apply international scientific capacity to solving of the problems of the world's disadvantaged people.

\section{CIFOR}

CIFOR was established under the CGIAR system in response to global concerns about the social, environmental and economic consequences of loss and degradation of forests. It operates through a series of highly decentralised partnerships with key institutions and/or individuals throughout the developing and industrialised worlds. The nature and duration of these partnerships are determined by the specific research problems being addressed. This research agenda is under constant review and is subject to change as the partners recognise new opportunities and problems. 


\section{Contents}

$\begin{array}{lr}\text { Abstract } & 1 \\ \text { Introduction } & 1 \\ \text { Some basic concepts } & 3 \\ \text { Forest decline: What is it? } & 3 \\ \text { Agents and direct and underlying causes of forest decline } & 4 \\ \text { Causation chains } & 5 \\ \text { Linkages between agents } & 6 \\ \text { The problems of inadequate definitions and data } & 7 \\ \text { Underlying causes } & 7 \\ \text { Market failures } & 7 \\ \text { Mistaken policy interventions } & 10 \\ \quad \text { Transportation policies } & 10 \\ \text { Subsidy policies } & 11 \\ \text { Policies that led to unmanageable international debt } & 13 \\ \text { Structural adjustment policies } & 14 \\ \quad \text { Log export bans } & 15 \\ \text { Institutional factors } & 16 \\ \text { Policies that favour concentration of ownership } & 16 \\ \text { Land tenure policies } & 16 \\ \text { Illegal activities and corruption } & 17 \\ \text { Broader socio-economic underlying causes } & 18 \\ \text { Population growth and density } & 18 \\ \text { Economic growth } & 19 \\ \text { Conclusions and policy implications } & 20 \\ \text { Bibliography } & 23\end{array}$




\section{List of tables}

Table 1. Consequences of continuing forest decline (from the perspectives of different segments of society).

Table 2. Comparing local and global market and non-market values: some examples (US\$ per hectare).

Table 3. Examples of policy failures that may lead to forest decline. 10

Table 4. Examples of underpricing forest resources in concession agreements.

\section{List of figures}

Figure 1. The causes of forest decline.

\section{List of boxes}

Box 1. Poverty, time horizons and environmental degradation. 9

Box 2. Why do some concessionaires in Indonesia exploit forest in unsustainable ways?

Box 3. Structural adjustment and the forests of Bolivia.

Box 4. A catalogue of illegal acts that promote deforestation and forest degradation.

Box 5. Population and Forest Cover in Indonesia.

Box 6. Economic growth and forest decline.

Box 7. The Environmental Kuznets Curve in Reverse: 


\title{
The Underlying Causes of Forest Decline
}

\author{
Arnoldo Contreras-Hermosilla*
}

\begin{abstract}
Loggers, miners and rural communities all exploit forests in unsustainable ways in search of profits and means of subsistence. These are the primary actors in forest decline and their immediate motivations are the direct causes of deforestation and degradation. However, these motivations are determined, through complex causation chains, by deeper and much more fundamental forces: the underlying causes of deforestation. Effective action against forest decline requires an understanding of these underlying causes and their distant impacts on forests.
\end{abstract}

Underlying causes originate in some of the most basic features of society, such as the distribution of economic and political power, attitudes towards corruption, population growth, flaws in the market system and also in seemingly unrelated government policies. They may originate in other countries and transmit their effects through trade and the operation of transnational corporations. Underlying causes are many and operate in numerous and variable combinations.

Forest decline is a complex socio-economic, cultural and political event. Thus, it is mistaken to attribute forest decline to a simple cause-effect relationship or assume that a relationship will remain unaltered over time. A single force, such as agricultural intensification, may operate in diametrically opposite ways, depending of the context of other variables and circumstances prevailing in a particular situation. Accordingly, remedial measures need to be tailored to the very specific milieu in which they will be introduced. There are no simple solutions to this complex phenomenon.

\section{Introduction}

According to the World Resources Institute, the world has lost about half of its forest cover. Despite a number of initiatives to stop forest decline, the world continues to lose some 15 million hectares of forests every year. Deforestation over the period 1980-1990 reached 8.2\% of total forest area in Asia, 6.1\% in Latin America and $4.8 \%$ in Africa. Most modern deforestation takes place in developing countries, particularly in tropical areas. The process generates large amounts of carbon dioxide equivalent to $20 \%$ of global emissions from fossil fuels, making deforestation the second most important contributor to global warming - and results in annual degradation of some 12 million hectares of fertile land and loss of thousands of species (estimates range between 8,000 and 28,000 per year). Deforestation and forest degradation directly threaten as many as 400 million people - including 50 million forest indigenous people who depend on forests for subsistence. Forest decline, resulting from the enormous human ability to alter large forest ecosystems is the source of intense conflicts between rural populations, governments, commercial interests and, increasingly, sections of the public at large.

Forest decline is often an undesirable phenomenon. Nevertheless, it is not always harmful. As with most human interventions, forest decline yields positive and negative impacts. A judgement on whether deforestation and forest degradation are undesirable depends on an assessment of their positive and negative impacts on the economy, environment and other dimensions of life, and on the importance that various groups in society attach to those impacts. Thus, for some, deforestation is desirable because it results in financial gain. For others, the negative environmental and social impacts of deforestation may be more important. Perspectives and values can be very different (see Table 1). An assessment of the positive and the negative is not an easy task because it is necessarily loaded with value judgements.

However, much of the human-induced deforestation and forest degradation is, in varying degrees, economically wasteful and environmentally negative, as well as socially undesirable. Often, just a few individuals benefit. The process usually induces adverse effects on the social condition of weaker sectors of society and leads to the progressive impoverishment of ecosystems. Some types of deforestation and forest degradation result in costs to society that amply exceed benefits (no matter how these are measured), and are simply "inappropriate".

\footnotetext{
* The author is a Senior Natural Resources Economist of the World Bank in Washington and the former Principal Economist of the World Commission on Forests and Sustainable Development in Geneva. E-mail: mitcon1720@aol.com
} 
Table 1. Consequences of continuing forest decline (from the perspectives of different segments of society).

Societal Group Implications of Continuing Forest Loss and Degradation

\section{Forest-dwelling indigenous} communities

Forest farmers and shifted cultivators

Local communities, the poor and landless living outside forests

Urban dwellers

Commercial forest industrial companies and forest worker communities

Mining, oil exploration and other industrial interests

Environmental advocacy groups and conservation agencies

The global scientific community

National government planners and decision makers
- Loss of spiritual values.

- Social disruption of traditional structures and communities. Breakdown of family values. Distress and social hardship.

- Loss of traditional knowledge of how to use and protect forests in sustainable ways.

- Reduced prospects for preservation of forest environmental and aesthetic functions of interest and potential benefit to society as a whole.

- For shifted cultivators, an immediate opportunity to survive.

- Forest degradation and declining soil fertility.

- Loss of access to forest land and the possibility of food crop production and reduced possibilities for harvesting forest products, both for subsistence and income generation.

- Prospects of malnutrition or starvation.

- Disruption of family structures and considerable social hardship.

- Decreased availability of essential fruits, fuelwood, fodder and other forest products.

- Reduced agricultural productivity. (Through loss of the soil and water protection potential of remnant woodlands and on-farm trees: loss of shelterbelt influence leading to reduced crop yield.)

- Reduced income generation and possibilities to escape from the poverty trap.

- In developing-country situations reduced availability (and/or overpriced) essential forest products such as fuelwood, charcoal, fruits, building materials and medicinal products.

- In developed countries, loss of the amenity and recreational values of urban forests and parks.

- Reduced prospects for assured supplies of clean drinking water and clean air.

- Loss of the recreational opportunities and amenity values afforded by national forest parks and wilderness areas.

- Immediate large profits.

- In the longer term, loss of company business and forced closure of forest operations.

- Loss of jobs for forest-dependent communities, social disruption and hardship.

- Loss of income and possible negative social implications of reduced income of shareholders with significant savings invested in forest industrial company stocks.

- Improved access to potentially profitable mineral, oil or other commercially valuable products located under forests.

- Increased profitability of company operations and returns to company shareholders.

- Politically negative impact on company operations of criticism by environmentally concerned groups.

- Loss of the essential environmental functions of forests including biodiversity, climate regulation, preservation of water catchments and fishery values.

- Loss of cultural values and social hardship for the underprivileged communities whose welfare these groups are committed to protect.

- Increased problems of environmental pollution.

- Loss of those forest values that could be of vital importance and/or interest to the survival and welfare of future generations.

- Prospects that continued forest destruction will accelerate global warming with potentially negative consequences for human welfare and survival.

- Continuing biotic impoverishment of the planet, loss of genetic resources, and all that implies for sustainable food production, and loss of potentially valuable medicinal and other products.

- Increasing pollution and toxification of forest soils, contributing to declining forest health.

- Immediate escape from political pressures when impoverished populations migrate to frontier forest areas.

- Loss of a potential source of development revenues with consequences of reduced employment and opportunities, sustainable trade and economic development.

- Loss of the wide range of environmental functions that forests provide in contributing to societal needs and a habitable earth.

- Loss of political support in situations where forestry loss and degradation adversely affect the welfare of many citizens. 
If this is so, why do inappropriate deforestation and forest degradation occur? This document explores the underlying causes of forest decline. First, we examine the concept itself and the distinction between agents and direct and underlying causes. We then focus on a selected set of underlying causes of forest decline. The last section summarises our main findings. The document draws heavily on research results from the Center for International Forestry Research (CIFOR).

\section{Some basic concepts}

\section{Forest decline: What is it?}

Forest decline here is interpreted as deforestation, forest degradation or a combination of both. These terms are not precise. The Food and Agriculture Organization of the United Nations defines deforestation as the "sum of all transitions from natural forest classes (continuous and fragmented) to all other classes" (FAO 1997). The loss of forest cover attributed to these transitions must occur over less than $10 \%$ of the crown cover for the phenomenon to qualify as deforestation.

It is not clear whether this refers to substantial areas or to, say, a particular hectare. What is the area that can be considered as under "fragmented" transition? Should such transition involve a minimum of, for example, 10 hectares to qualify as deforestation? FAO suggests that a minimum of 0.5 hectare is needed to qualify as forest and therefore loss of crown cover to less than $10 \%$ for at least this area would presumably qualify as deforestation (see, for example, FAO 1994). This, however, is not universally accepted. Operationally, this level of precision $(0.5 \mathrm{ha})$ may be unattainable, particularly in developing countries.

Furthermore, such transitions have a time frame. What if the transition to other uses involves, for example, 20 years and then the area reverts to forest cover? Is that deforestation? What is the minimum period of time necessary for a certain area to qualify as "deforested"? FAO indicates that areas that are "temporarily" understocked but which are expected to revert to forests should be considered as forests. It is, however, difficult to render this concept operational as its interpretation depends on the period of time that can be considered as "temporary" and on the highly speculative nature of the expectation that the area may eventually revert to forest.

As FAO (1998) recognises, these definitions do not enjoy universal acceptance.
Some analysts consider forest plantations as different from "forests", reserving the latter label as appropriate for natural forests only (we will not go into the many problems created by the introduction of the concept of natural forests, because "natural" is a term that is difficult to define unambiguously). Under this interpretation, the loss of natural forest and its replacement by forest plantations would be defined as deforestation, even if the tree crown cover may be more than $10 \%$. We prefer to follow the FAO definition that considers as forest any tree formation, provided that the minimum level of crown cover is present.

In addition to deforestation, forest degradation is an issue. According to FAO, changes within a forest class, for example from closed to open forest, which negatively affect the stand or, in particular, lower its production capacity, constitute forest degradation. Thus, forest degradation implies a major loss of forest productive capacity, even where there is little deforestation as such. FAO (1998) states:

Forest degradation takes different forms, particularly in open forest formations, deriving mainly from human activities such as overgrazing, over-exploitation (for firewood or timber), repeated fires, or due to attack by insects, diseases, plant parasites or other natural causes such as cyclones. In most cases, degradation does not show as a decrease in the area of woody vegetation but rather as a gradual reduction of biomass, changes in species composition and soil degradation. Unsustainable logging practices can contribute to degradation if extraction of mature trees is not accompanied with their regeneration or if the use of heavy machinery causes soil compaction or loss of productive forest area.

Productive capacity in what sense? Capacity to produce timber or other goods and services of forests? What if the timber production of the forest suffers in terms of quantity, but quality of future non-timber production increases? Or, what if the timber productivity falls but the aesthetic values of the forest increases? Is this still forest degradation?

The following sections should be read with an awareness of these conceptual limitations. Several studies of deforestation may use different definitions.

Even recognising the importance of exact definitions, the case for precision should not be exaggerated. Causes of major undesirable forest interventions can be analysed and practical implications for policy making derived, 
even in a world with a relative lack of pure conceptual definitions. Thus, in this article, forest decline would loosely include deforestation, understood as the reduction of tree crown cover to less than $10 \%$ of the total area for rather large areas and for long periods of time. We will not attempt a rigorous definition of "large area" and "long periods of time", which would be arbitrary anyway. Forest decline would also include degradation, again loosely understood as a loss of some of the main attributes of forests, be these the capacity to produce timber, wood, non-wood products, environmental services or a combination of all these. Here we are more concerned with the causes of these processes than with the conceptual precision of the terms "deforestation" and "forest degradation".

\section{Agents and direct and underlying causes of forest decline}

Forest decline is the result of actions by a number of agents. Agents are individuals, groups of individuals or institutions that directly convert forested lands to other uses or that intervene in forests without necessarily causing deforestation but substantially reducing their productive capacity. Agents include shifted cultivators, private and government logging companies, mining and oil and farming corporations, forest concessionaires and ranchers. These agents clear forest lands or selectively exploit forests for agricultural expansion, to subsist, for mining, to obtain forest products and fuelwood, etc.

Loggers are usually blamed for most of the deforestation and degradation that takes place in the world. However their actions in the tropics are often limited to the extraction of a few trees per hectare and therefore they do not directly deforest large areas. Even so, by building roads and facilitating access, loggers open vast areas to other agents such as landless migrants. Their interventions also cause forest degradation as they remove the most valuable species of trees and the logging operations generally produce substantial damage to the remaining stands.

This is also often the case of miners and oil operators. Some mining activities, such as open pit mining and small-scale mining, cause great direct damage to forests. The construction of access roads and the penetration of forest areas by other agents compound this effect.

Agents act with different intensities in various regions and countries. In tropical Latin America, landless peasants in search of public forest lands to grow crops for survival and cattle ranchers, in some cases supported by governments, are important agents of deforestation. In Ecuador, Peru and Venezuela, mining corporations and individual miners clear large areas of forests (MineWatch 1997; Miranda et al. 1998). Commercial farmers have cleared forests for soybean exports in Brazil, Bolivia and Paraguay. Illegal miners have incurred great damage to Venezuelan forest resources, as well as causing other environmental problems (Miranda et al. 1998). Loggers searching for valuable woods degrade forests and facilitate deforestation in the Guyana Shield.

In North America, oil companies have identified for possible exploitation the extensive oil sands in Alberta, which are largely under forests. If oil sand projects were implemented, they would pose a great threat to the boreal forests of Canada. ${ }^{1}$ Loggers are claimed to be important agents of degradation in the forests of the US Pacific Northwest and Western Canada.

They are also critical actors in deforestation and forest degradation in Southeast Asia and Siberia. Agricultural concerns clear large tracts of forest lands in Malaysia and Indonesia to establish agro-industrial plantations (Kartodiharjo and Supriono 2000). Fuelwood collectors deforest and degrade areas around South Asian cities.

Loggers are again the main agents of forest decline in Central and West Africa. But are peasants as well as fuelwood collectors are also important in drier areas of the Sahel. Pastoralists are particularly active in the Sudano-Sahelian and Eastern African subregions, where remaining trees and woodlands are under the most severe pressure for dry season browse and fodder. Wood supplies $70 \%$ of total energy use in Sub-Saharan Africa, and fuelwood collectors account for over $85 \%$ of the wood removed from the forests and woodlands. Loggers selectively exploit forests in various forest-rich countries of Africa, setting the stage for deforestation by other agents.

Agents deforest and degrade forests for complex reasons and conditions in their decision-making environments. Their decisions to expand agricultural operations, cattle ranching, logging, etc. immediately impinge upon forests. They are in search of commercial profits, or means of subsistence. We call these motivational factors the direct causes of deforestation. They are the most apparent causes.

\footnotetext{
${ }^{1}$ The Alberta oil sands occupy a vast area of boreal forests, about the size of New Brunswick, and contain about one-third of the world's oil resources - even greater than Saudi Arabia's reserves.
} 
But these direct causes are in turn influenced, or even determined, by more fundamental forces, some of which originate in spheres that may be quite distant from, and apparently unrelated to, decisions by the main agents. It is plausible, for example, that population growth and density affect the size of markets and the demand for forest products as well as decisions made by logging corporations. Macroeconomic policies contribute to changing the structure of economic and political power of society and create changing relationships between humans and forest resources. These distant origins, sometimes far removed in the causation chains from the deforestation agents and their immediate actions, are the underlying forces of deforestation. Most of these underlying forces originate in the very nature of society, in the ways human societies organise themselves. Some originate in other countries and transmit their influence through trade or the action of international agencies and transnational corporations. Regardless of their geographical sources, economic and political power structures, traditions and culture are the origin of attitudes, values and ultimate behaviour affecting forests at the local level.

Interactions exist between agents and direct and underlying causes of forest decline (Figure 1). There are natural causes of forest decline such as natural fires and hurricanes. The recent great fires of Indonesian forests are a dramatic example of this source of forest loss. We will not deal with these because they cannot be easily influenced by policy interventions. For similar reasons we will also omit some broad forces such as war, global warming and the distribution of economic and political power.

\section{Causation chains}

The literature exploring underlying causes of forest decline is plagued by imprecision for several reasons. First, the separation between direct and underlying causes is not as neat as most would like it to be. In reality, there are long causation chains that eventually lead to the act of deforestation. And, depending on the perspective of the analysis, individual causes can also be viewed as the effect of still higher causes.

In this sense causes are hierarchical. For example, a hypothetical chain of causes and effects may operate in this way: shifted cultivators deforest because they need to provide a means of survival for their families. This is because they are poor and have few alternatives to deforestation. They are poor because present power structures discriminate against a large number of people who therefore have little or no access to alternative means of survival. Present power structures originated in historical arrangements such as colonisation. Thus, in this theoretical example, there is a causation chain that starts with colonisation and runs along unequal control over key resources, to poverty and the need to survive and, finally, forest decline. What is the underlying cause of deforestation? Is it poverty? Or inequity in the control over resources? Or colonisation? Or a mix in various proportions of these factors?

It is not surprising that the debate about causes of deforestation is often confusing. Those analysts who travel a short distance back in the causation chain that leads to deforestation may argue that poverty is an underlying cause. Others, looking further back in the

Figure 1. The causes of forest decline.

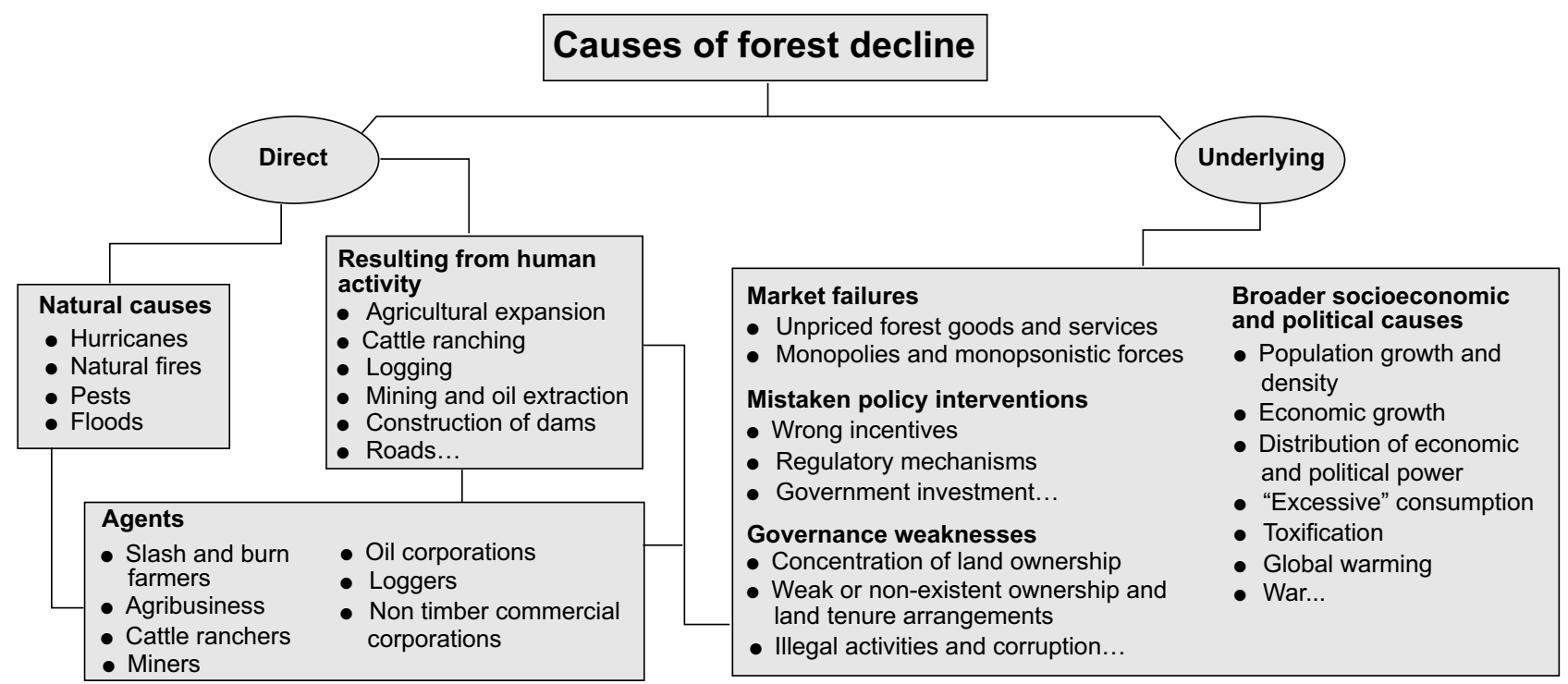


linkages will argue that the real underlying cause is in fact the unequal political and economic power structures, which in turn are rooted in the foundations of society and that, instead, poverty is nothing but the effect of such power structures. For them, poverty is the result of another underlying cause operating at a higher level.

This differentiation may appear as theoretical curiosity only and not deserving much attention from those interested in designing strategies to change the present state of affairs. It is easy to fall into the trap of considering this hierarchical structure of causes and effects merely as a banal distinction. However, although apparently unimportant, the implications of this distinction in terms of policy making are profound. In our example above, analysts who conclude that the underlying cause of deforestation is poverty will tend to issue policy prescriptions to accelerate income growth and to combat poverty. These usually consist of different combinations of formulae for "getting prices and government policies right". But the group of thinkers who see deforestation as the result of unequal power structures will issue prescriptions to address changes in social, economic and political relations required to alter ways by which different groups gain control of productive assets. These may include radical changes such as agrarian reforms and expropriation of productive assets. The difference is clearly not inconsequential. The interpretation of the "cause", and therefore its neutralisation, imply fundamentally different strategies.

The second source of imprecision in the literature, in contrast to the example above, occurs since cause-effect chains are seldom linear or unidirectional. Instead, there are many branches that in turn constitute secondary causeeffect loops leading to forest decline. There are also some important feedback effects working in the opposite direction. For example, the unequal distribution of control over resources may not only lead to poverty but also to large families, increased population pressure, lack of technical knowledge, difficult access to credit and so on. Each one of these may constitute the origin of a force leading to forest decline. When these causal branches and loops are included in the analysis of forest decline, the number of "causes" increases substantially. The large number and range of variables associated with deforestation are described in an analysis carried out by CIFOR of 150 formal modeling exercises around the world (Kaimowitz and Angelsen 1998).

Feedback loops complicate analyses of the causes of forest decline. For example, a logging company may construct harvesting roads that facilitate the occupation of forest lands by small farmers. After some time, these farmers may be able to successfully lobby politicians not only to improve these roads but also to build new roads, thus making it easier for new migrants to obtain access to forested areas located further away. In this case, roads lead to forest land occupation and land occupation leads to building more roads and the further occupation of forested land in a circular self-reinforcing loop of cause and effect relationships.

Thus, it is simplistic to conclude that forest decline is "caused" by a single culprit, such as economic expansion or trade. Reality is much more complex. Multicausal chains are more likely and the effect of a single force, such as poverty or roads, is very difficult to ascertain.

Thirdly, causal factors are likely to vary over time, sometimes drastically. At certain stages of development, rapid income growth could promote forest decline by, for example, increasing demand for forest products and by enhancing the human capacity to alter forests. But, as development, economic expansion and affluence take place, population rates may decrease, demand for environmental services expand and government may become more efficient. Depending on the circumstances and the nature of these forces and their effects on demand, income growth may be, at different points in time, both a cause of forest decline and of more sustainable forest management.

\section{Linkages between agents}

Agents of forest decline are seldom, if ever, totally independent from each other. This makes it difficult to isolate their individual contributions to deforestation at a given point in time or geographical space. Their relative importance over time may also change. Thus various agents could operate at the same time or sequentially in either the same or in a different location. For example, cattle ranchers may obtain access to lands by deforesting but also by inducing landless peasants to do the job for them. With the possibility of having their land legally acquired through occupation, and subsequent sale of property to cattle ranchers, landless peasants can be effective - and dependent - agents of deforestation. Some logging companies are known to supply local populations with power saws and then buy their production of logs, often obtained illegally from protected areas, thus expanding the area deforested. When agents operate at the same location, competition may induce more rapid deforestation. In other cases, a powerful agent, for example a logging corporation, may be able to keep competitors at bay thus reducing overall rates of 
deforestation. Without knowing the forms of interactions between agents, it is risky to derive conclusions about the importance of their individual roles.

\section{The problems of inadequate definitions and data}

We have highlighted the conceptual lack of precision surrounding some of the key elements of forest decline. Empirical studies also face the obstacle of very inadequate data. This prevents the empirical validation of plausible cause and effect relationships. For example, the World Bank (1994a) lists several studies on rates of deforestation in Indonesia which, depending on methodologies and definitions, produced estimates ranging from 263,000 to $1,315,000$ hectares per year. Similar situations exist in other countries. Data are often spotty, unreliable and not comparable.

We have presented a formidable list of obstacles to the unambiguous identification of the underlying causes of forest decline. This should not come as a surprise because the process is rooted in the complexities of the political, economic and social features of societies, and the nature of their evolution over time and over geographical spaces. Very complex issues do not lend themselves to simple answers. But complexity does not mean that it is impossible to produce intelligent analyses leading to practical decisions. What we need to keep in mind is that the analysis of cause and effect linkages possibly will have to be adjusted by considerations of the specific situation, country or region under analysis, where these numerous and interacting forces may operate in different combinations and with different intensities.

\section{Underlying causes}

As underlying causes are so numerous and interrelated, their study necessarily must be selective. First, we will discuss some of the weaknesses, or outright deficiencies, of the market that produce signals that eventually induce forest decline. Second, we will examine actions by governments - regulations, monetary or other policies, direct investments - that influence actors' motivations, sometimes producing incentives to deforestation and forest degradation. Next, we will consider particular governance factors that contribute to forest decline weak land ownership rights, illegal activities and corruption. Finally, a selected group of underlying socioeconomic causes that are hybrids between market forces, policy and institutional factors will be studied in some detail. These include population growth and density as well as economic expansion.
Our discussion will leave out some underlying causes. These include armed conflict, "excessive" consumption, global warming and toxification. This does not mean that these factors may not be important. For example, the effects of war on the forests of Vietnam and Cambodia were very substantial. War in parts of Africa is also known to have affected forests. In addition, many analysts believe that patterns of consumption in the North (and of the rich in the South) are important causes of forest decline in the South. With respect to toxification, it is estimated that the Chernobyl nuclear disaster alone degraded some 7 million hectares of forests in Russia, Belarus and Ukraine (FAO 1997). A survey of 29 countries has shown that more than one-fourth of the trees in Europe suffer from defoliation; in some cases, atmospheric toxification kills trees and, in others, it substantially reduces valuable attributes such as the capacity to produce wood and protect soils. A number of researchers predict that global warming will eventually lead to a very substantial decline of the world's forests. However, although some of these causes may have an important effect on forests, they are very far removed from the forestry sector (e.g. war), are based on concepts that are difficult to address analytically (what is "excessive" consumption?), or their effects are simply quite uncertain because of a lack of incontrovertible scientific evidence of long-term impacts (e.g. global warming). We will, therefore, omit these causes from the present discussion.

\section{Market failures}

Deforestation and forest degradation are ultimately the result of decisions by agents such as private entrepreneurs, corporations, shifted cultivators and communities. Generally, the main agents in the process of deforestation and forest degradation belong to the private sector. An underlying cause of deforestation is the discrepancy between values of these private agents and those of society. Because of this, the satisfaction of the agent's objectives may be in conflict with the satisfaction of society's objectives.

A distinction must be made between the values accruing as a consequence of deforestation and forest degradation to the agent and those accruing to society generally. Society may be a region, a nation, or the world in general. Values of private agents and those of society as a whole are likely to diverge for several reasons. Many of the services provided by forests (as well as some of the costs of mismanaging these resources) have no market price and therefore do not enter into the decisions of private sector actors. For example, a forest landowner in an upper watershed does not get paid for the services his forest provides to downstream fishermen and farmers. These 
values, including protection of soil against erosion and irrigation and hydropower dams against sedimentation, can be substantial to downstream operators.

Nor does the landowner obtain commercial profits for capturing carbon, maintaining scenic beauty or for preserving biodiversity resources. The forest landowner has little incentive to take these benefits into account and therefore the production of these environmental services will be less than if he could sell them and receive a financial reward.

In all cases where the forest landowner does not obtain the full value of social benefits provided by forests, there will be less incentive to maintain lands under forest cover. The market fails to generate the signals that would lead private operators in the direction of satisfying social objectives. In many cases, Adam Smith's "invisible hand" fails and signals the wrong priorities to private sector decision makers. Frequently, for the reasons already set out, these signals lead to forest decline.

Forests provide local and global unmarketable benefits which may accrue to distant consumers. Any loss of these benefits must be considered costs. For example, a slash and burn farmer does not pay for the global cost of increased carbon dioxide released into the atmosphere or for the increased costs of protecting dams downstream that result from his actions. Nor for the loss of biodiversity or aesthetic resources associated with the forest he exploits. Although these costs may be important for society as a whole, they are far less important for the private agent of forest decline.

If private agents are not compensated for the values of forests that do not have a financial, marketable dimension, they will be less interested in managing forests. If they do not have to pay for some of the costs of depleting forests, they are more likely to convert forested lands to other uses.

A number of questions arise. Are all these non-market values important? How significant is this source of forest decline? And, if these benefits that have value for society but not for the private agent could somehow be "internalised", would they help combat undesirable forest decline?

Various analysts have attempted to estimate the magnitude of unpriced forest values. For example, in their appraisal of project effects, the World Bank routinely estimates the economic magnitude of external benefits and costs, adjusting the estimates of project impacts for imperfect and non-existent market values. These appraisals also routinely show that the balance of benefits and costs of projects, including these "external" nonpriced impacts, is more favourable than that resulting from the simple comparison of marketable benefits and costs. This suggests that if it were possible to alter market forces to take these values into account, there would be a higher chance that some forest lands would not be deforested or degraded because they would be more valuable to the private agent.

This chance would be higher if these values of forests were considerable. Pearce (1995) and others have attempted to produce a consolidated picture of the value of non-marketable benefits of forest resources (see Table 2). Results should be interpreted with caution. Great differences exist from location to location and methodologies are not strictly the same. Moreover, this comparison contains only one side of the picture, that is, the benefits side. Still, some interesting conclusions emerge.

Table 2. Comparing local and global market and non-market values: some examples (US\$ per hectare).

\begin{tabular}{lrrrrr}
\hline & Mexico & Costa Rica & Indonesia & $\begin{array}{r}\text { Malaysia } \\
\begin{array}{c}\text { Peninsular } \\
\text { Malaysia }\end{array}\end{array}$ \\
\hline Timber (market value) & - & 1240 & $1000-2000$ & 4075 & 1024 \\
Non-timber products (market and non-market values) & 775 & - & $38-125$ & $325-1238$ & $96-487$ \\
Carbon storage (non-market value) & $650-3400$ & 3046 & $1827-3654$ & $1015-2709$ & 2449 \\
Pharmaceutical (non-market value) & $1-90$ & 2 & - & - & $1-103$ \\
Ecotourism/recreation (market and non-market values) & 8 & 209 & - & - & $13-35$ \\
Watershed protection (non-market value) & $<1$ & - & - & - \\
Existence or non-use value (non-market value) & 15 & - & - & - \\
Option value (non-market value) & 80 & - & - & - \\
\hline
\end{tabular}

Note: Non-timber products refers to resins, nuts, mushrooms, wildlife and other forest products, some of which have market values. Option values relate to the non-market value of preserving forests for future use. Existence values are those attached to forests by people, even if they will not use these forest resources.

Source: Adapted from Pearce (1995) 
First, some of the non-market benefits of forests are indeed important, in some cases close to the commercial value of timber. Second, and against popular belief, the potential economic value of some services, such as the development of medicinal drugs from tropical forests, is low. The value of this potential is normally thought to be high, but research indicates that this is not the case. The main reason is that the probability of discovering a drug is very low in per hectare terms. The aggregate value of ecotourism and recreation is also limited, although the value of recreation may be very high in particular locations. If captured, this value could contribute significantly to arrest forest decline in these locations. The same can be said with respect to watershed protection values.

Third, the only non-market global value that appears to be of a high importance is that of carbon sequestration. Even this figure is uncertain, as there is some disagreement about the actual amounts of carbon sequestered in different latitudes, under various ecological conditions and the silvicultural treatment applied. Also, there is no agreement on the price that can be attributed to a tonne of carbon. According to different authors, this price ranges from US\$ 5 to some US\$ 30 or even US\$ 50 per tonne. Despite this limitation, carbon sequestration appears as the most important global nonpriced service of forests.

In summary, the failure of markets to account for nonpriced benefits and costs may, in various circumstances, be an important underlying source of forest decline, shaping the actions of private agents in directions that are biased against the conservation and protection of nonpriced benefits. Efforts to reduce deforestation and forest degradation and to improve forest management to bring it more in line with social priorities - as opposed to exclusively private preferences - must rely heavily on commercial systems that would be able to capture some of the external values of forest resources, most notably, carbon sequestration values.

Many argue that society will probably "discount" the future in a different way to a private agent. It is generally believed that society discounts the future at a lower rate because of its longer "life" and because of its obligations to future generations. Private agents may not have these obligations, at least not to the same extent. Forest endeavours frequently imply long gestation periods and they are less desirable to private investors interested in relatively quick results. Such investors would not be as interested as society in benefits that will materialise in the distant future, as private persons are less likely than society to enjoy them. The poorer the decision makers, the more myopic their consumption and production perspectives are likely to be, causing them to deplete forests for immediate benefit, no matter how important future costs may be. Thus, the World Bank Forestry Policy (1991) states that high private discount rates, particularly among the poor populations that depend on forests, are a cause of deforestation. Pearce and Warford (1993) argue that:

High discount rates are one cause of environmental degradation because they encourage individuals to opt for short term measures that satisfy immediate needs or wants and ignore more environmentally appropriate practices such as planting trees.

There is no market to take account of this divergence between private and social preferences.

The hypothesis that the poor have a higher discount rate and are more inclined to deforest is confirmed by various studies and by the commonly observed fact that they are willing to borrow in informal markets characterised by very high interest rates. There is empirical evidence that poverty is often associated with higher levels of deforestation. But this commonly held view is sometimes challenged. A recent World Bank examination (Ekbom and Bojö 1999) of the linkages between poverty and environment quotes various analysts who contend that poverty does not necessarily lead to shorter time horizons and environmental degradation (see Box 1). These researchers show how, in certain circumstances, the rural poor used resources in a sustainable manner for long periods of time, even for centuries.

Box 1. Poverty, time horizons and environmental degradation.

Ostrom (1990) identifies a number of conditions that would lead to long-term sustainable management of common pool resources by the poor, despite their short time horizons:

1. The geographical boundaries of the common pool resources must be clearly defined.

2. Appropriation of benefits and local economic, social and environmental conditions must be compatible.

3. There must be a consensus about collective choices.

4. There must be an adequate monitoring system.

5. There must be an effective system of sanctions for those who violate the rules.

6. Inexpensive conflict resolution systems must be in place.

7. Government must recognise the right of people to organise themselves.

8. All the above principles should conform to a package that is coherent at the local, regional and national levels and implemented at the lowest possible level of decision making. 
These studies show once more that assumptions tying the results of resource management to one or few "causes" are simplistic, and that in reality there is a host of interacting factors influencing the decisions of people who have an impact on forests.

\section{Mistaken policy interventions}

Policy interventions may create obstacles to the sustainable management of forests. These actions are not always purposely biased against forests but often this is their unintended result. In many cases they constitute a failure to address market failures. As expressed by Repetto (1993):

Governments, many of which are committed in principle to conservation and wise resource use, are aggravating the loss of the forests under their stewardship through mistaken policies. Such policies, by and large, were adopted for worthy objectives: industrial or agricultural growth, regional development, job creation, or poverty alleviation. But such objectives typically have not been realised or have been attained only at excessive cost.

Policy interventions can contribute to deforestation in many ways (see Table 3).

\section{Transportation policies}

Governments normally are responsible for the construction of major roads such as the TransAmazon highway, the TransBorneo road and the Carretera Marginal de la Selva. Roads are built by governments for a variety of reasons including the desire to provide better access to timber resources, to promote farming or for national security reasons. Many pass through or near forests. Sometimes private corporations, such as mining and oil companies, also construct major roads, but almost invariably with the authorisation of governments. The road system of a country is largely the result of government policies.

Policies to promote or allow the construction of roads near or through forests, lead to deforestation. Mahar and Schneider (1994) contend that "road building is the single most powerful element in the deforestation of frontier areas in Latin America". ${ }^{2}$ Between 400 and 2000 hectares may be deforested by each kilometre of new road built into forests. Apart from facilitating physical access, roads alter economic values and increase the profitability of converting forest land to agriculture. Also, roads push land values up and thus make land more attractive to illegal occupants.

Economic models of deforestation show a close association between greater access to forests and

Table 3. Examples of policy failures that may lead to forest decline.

\begin{tabular}{|c|c|}
\hline $\begin{array}{l}\text { Direct government investment in the forest } \\
\text { sector or in related sectors }\end{array}$ & $\begin{array}{l}\text { - Road construction } \\
\text { - Hydropower investments }\end{array}$ \\
\hline Government command and control regulations & $\begin{array}{l}\text { - Conservation area protection } \\
\text { - Obligation to replant harvested areas } \\
\text { - Prohibition to harvest without a permit } \\
\text { - Obligation to prepare forest management plans as condition for intervening } \\
\text { in forest areas } \\
\text { - Log export bans }\end{array}$ \\
\hline Fiscal, price or monetary policies & $\begin{array}{l}\text { - Subsidies affecting forest raw materials or other inputs } \\
\text { - Subsidies affecting competitive uses of lands, such as cattle ranching } \\
\text { - Plantation subsidies } \\
\text { - Price controls } \\
\text { - Subsidies affecting forest harvesting or manufacturing } \\
\text { - Forest products taxes } \\
\text { - Subsidised credit } \\
\text { - Foreign exchange policies affecting competitive uses of lands }\end{array}$ \\
\hline Provision of services & $\begin{array}{l}\text { - Delimitation, demarcation and land titling } \\
\text { - Actions to promote exports } \\
\text { - Settlement of frontier areas }\end{array}$ \\
\hline
\end{tabular}

Various analyses have shown that policies in sectors other than forestry - roads, mining, agriculture, land tenure have a great impact on forest decline; normally a much more substantial impact than that of forest policies.

\footnotetext{
${ }^{2}$ See also Bryant et al. (1997)
} 
deforestation. CIFOR examination of some 150 models of deforestation (Kaimowitz and Angelsen 1998) suggests that:

Forest fragments are more accessible than forest compacts and forests in coastal countries and islands are more accessible than in continental countries. Roads seem to have a stronger impact in regions dominated by commercial agriculture and areas with better soils, than in marginal lands inhabited mostly by small farmers that practise slash and burn cultivation.

Government-sponsored road construction and the onset of deforestation are frequently easily observable circumstances in various tropical countries. For example, in the Brazilian state of Pará, deforestation following road construction increased from $0.6 \%$ to $17.3 \%$ of the state's area between 1972 and 1985. Although in theory some of the negative impacts of roads policies could be mitigated, in practice governments do not have the inclination to do so for political reasons or simply because they cannot, given the limited administrative resources at their command.

The natural conclusion is that roads policies are underlying causes of deforestation. But, as plausible as this may seem, there is some question whether the underlying cause of deforestation is not the road policy itself but instead the motivation that created that policy. According to this view, frequently, roads are the result of a pre-existing desire to deforest on the part of some politically powerful group that is able to influence government policy, and not the other way around. In these situations, deforestation is the result of an initial propensity to deforest, with roads being a means to that end. For example, farmers may perceive good opportunities to convert inaccessible forested lands into profitable agricultural production and effectively lobby the government to build roads. In this case, roads policies are not the cause of deforestation but rather the effect of a desire to deforest that in turn is caused by a perception by influential interests that good commercial opportunities may exist in the development of currently inaccessible forested lands (Kaimowitzet al. no date). On the other hand, and taking this argument further, it is also possible to imagine that the roads constructed in deforested and settled areas may increase the desire to deforest more remote areas. The presence of roads is likely to increase the value of land in areas under the first round of deforestation, induce original settlers to sell and subsequently move further into marginal forested lands to start the process anew (Schneider 1995).

Of course, government policy is not always geared towards simply improving access to forested areas. One of the reasons for limited forest decline in the lowlands of Bolivia prior the agrarian reform was the desire of highlands interest groups to restrict movement of the labour force from the highlands, where it was needed for operating mines and estates. These groups largely succeeded in this endeavour by being able to exert enough power and shape government policies to serve their own interest (Kaimowitz 1997).

Reforms of road construction policies in order to reduce their negative incentives for unsustainable practices do not necessarily imply a reduction in road building or considerable economic costs. Often, simple changes in the design of road systems would produce a noticeable impact (Kaimowitz et al. no date). Furthermore, the political pressure to implement policies that promote the expansion of roads into forested areas may be less significant in the future. Sayer and Byron (1996) argue that logging in "frontier" tropical areas may become less important because of the erosion of their economic comparative advantage over plantations.

\section{Subsidy policies}

Governments often grant subsidies either directly to forest sector operators or to entrepreneurs in other sectors related to forests. Not infrequently, these subsidies unintentionally cause forest decline (Repetto 1993):

These subsidies can become so large that they encourage activities that are intrinsically uneconomic, or push alternative land uses beyond the limits of economic rationality. The effect of all such (subsidy) measures is to shift the margin of relative profitability between forest and the competing land use, encouraging more forest conversion than would otherwise take place.

The most common and important type of subsidy in the forestry sector is that implicit in the low forest charges paid by timber concessionaires. Large areas of public forests in the tropics are under concession contracts. ${ }^{3}$ Increasingly, various logging companies aggressively seek new timber concessions in forest resource rich countries. By 1997, about $30 \%$ of Guyana's forests were reported to be already under timber concessions (Wilkinson 1998). Almost 70 million hectares of the closed forests of Indonesia are assigned to about 650 timber concession schemes (Kartodiharjo and Supriono 2000). Practically all of Ghana's forest reserves are under the control of some 200 concessionaires (Gray 1997).

\footnotetext{
${ }^{3}$ Forest concessions are permits issued by governments for exclusive rights to assess forest production potential, to harvest wood or other forest products and to manage a specified area of public forests for a certain period of time.
} 
There is nothing intrinsically wrong with granting forest concessions except that government forest charges often bear little relationship to the market value of the resources and to the forest rents generated ${ }^{4}$ (see examples in Table 4). Why is the implicit subsidy in "underpricing" wood important in terms of deforestation pressures? The subsidy encourages logging companies to use wood wastefully, because subsidised wood becomes inexpensive (Vincent and Binkley 1992). There is also the incentive to obtain larger concessions than necessary, to log quickly (as it is uncertain for how long the concessionaire can hold onto the profitable concession) and carelessly. Further, concessionaires have little inclination to prevent illegal occupation of the concession lands by migrants that may practise slash and burn agriculture. Because logging rights in concessions usually are not transferable, there is very little motivation for the concessionaire to manage forest resources in a sustainable way. Finally, underpricing of wood reduces forestry department budgets that could be used to reduce wasteful and undesirable forest decline. Inappropriate concession policies are clearly a significant obstacle to sustainable forest practices (Box 2).

Table 4. Examples of underpricing forest resources in concession agreements.

\begin{tabular}{lccl}
\hline Country & $\begin{array}{c}\text { Period of } \\
\text { analysis }\end{array}$ & $\begin{array}{c}\text { Estimated economic forest } \\
\text { rent captured by government, } \\
\text { as proportion of total rent } \\
\text { (percentage) }\end{array}$ & Reference study \\
\hline Nicaragua & 1997 & $6-30$ & Gray and Hagerby 1997 \\
Venezuela & $19995-97$ & $2-3$ & Centeno 1995 \\
Indonesia & 1993 & $25-35$ & Collins 1993 \\
Indonesia & 1997 & 25 & Myers and Kent 1997 \\
Malaysia: Peninsular Malaysia & 1989 & $9-49$ & Vincent et al. 1993 \\
$\quad$ Sabah & 1991 & $53-64$ & Vincent 1991 \\
$\quad$ Sarawak & 1991 & $35-69$ & Vincent 1991 \\
Ghana & $1993-95$ & $7-13$ & Gronow 1996 \\
Cameroon & 1987.1991 \\
Cameroon & $1994-96$ & $2-4$ & World Bank 1997 \\
Cambodia & $1996-97$ & 22 & Global Witness 1997 \\
Colombia & 1991 & 9 & Motta 1992 \\
Belize & 1996 & $7-24$ & Contreras-Hermosilla 1998 \\
\hline
\end{tabular}

Note: Differences within countries may be due to different estimation procedures and/or to variable factors such as economic accessibility or market prices for wood products. Percentages are estimated on the basis of government revenues for various charges - such as timber charges, area fees, export taxes, etc., but generally excluding income (personal or corporate) taxes - divided by stumpage prices.

Box 2. Why do some concessionaires in Indonesia exploit forest in unsustainable ways?

- The method of concession allocation gives too much land to concessionaires. Certain concessionaires thus have low incentives to prevent encroachment by smallholders, or are unable to stop such encroachment. Low forest concession fees induce concessionaires to acquire vast forest areas. In addition the timber royalty fees in Indonesia are based largely on the volume of extraction rather than on the area of concession. This reinforces the tendency to obtain excessive concession areas. Concessionaires have little incentive or possibility to control encroachment and resulting deforestation if they have an excess area.

- Certain policies encourage rent-seeking behaviour and thus undermine incentives for long-term management. High profits resulting from low concession fees open the way for corruption and the enforcement of the terms of the concession contract is endangered. Moreover, concessionaires rush to exploit forest in a careless manner as the favourable conditions that generate high profits may not last. In addition in Indonesia, low fees and high export taxes depress the domestic price of timber, thus limiting the desire to invest in sustainable forest management. Considerations other than the soundness of forest management practices enter into the decision to grant concessions and thus undermine incentives for good performance.

- There is insufficient support for provincial-level protection of forests. In Indonesia, provincial governments receive a very small share of the already low timber concession fees. Provincial governments with extensive forests may prefer to replace them with other forms of land use that generate more revenue.

Source: Taken from Sunderlin and Resosudarmo (1996)

\footnotetext{
${ }^{4}$ Forest economic rents are returns from harvesting beyond those that could be earned elsewhere in the economy. Governments can capture part or all of these economic rents through a variety of forest charges. If governments do not capture these rents, they accrue to concessionaires as subsidies and exceptional profits.
} 
As with other underlying causes of forest decline, the cause-effect link between faulty concession contracts and deforestation and forest degradation is not always clear. Some governments establish subsidised timber concessions to open lands to economic opportunity and to provide means of livelihood for impoverished migrants. Governments occasionally justify subsidies embodied in timber concessions on grounds of employment creation, construction of infrastructure by logging companies and the push to promote local development. Generally, however, these are inefficient methods of achieving local development and beneficial impacts are seldom sustainable. Instead "boom and bust" situations are more common, where excessive and wasteful deforestation and forest degradation take place creating a momentary bubble of economic expansion that bursts as soon as forest resources are depleted or substantially degraded (Repetto and Gillis 1988). In 1995, the World Bank, referring to the dangers of faulty concession policies, issued warnings to the government of Guyana that "this kind of forest mining entails a boomand-bust pattern of development that can be highly disruptive to employment levels and macro-economic stability" (quoted in Friends of the Earth 1997).

Governments often grant direct or indirect subsidies to agriculture. This increases the profitability of agriculture and, if agricultural lands are scarce, the pressure to convert forested lands. Depending on economic conditions, increased agricultural profitability enhanced through subsidies (or other equivalent government policies) can lead to agricultural intensification, but often expansion into forested lands is a more profitable alternative. In Ghana, for example, government policies fostered extensive rather than intensive agriculture (Munasinghe and Cruz 1994).

Whether agricultural subsidies and the associated possibility to increase agricultural profitability will lead to either intensification (and reduced pressure on forests, as in the case of the green revolution) or extensification depends on the technologies adopted, the economic conditions facing farmers, the availability of different types of lands and the nature of subsidies. Not all agricultural subsidies lead to extensification and forest conversion into agriculture. Kaimowitz et al. (no date) argue that subsidies implicit in the development of irrigation facilities are more likely to lead to agricultural intensification because it is generally not convenient to supply irrigation facilities to remote areas at the forest frontier. This is not so if subsidies apply to rural roads, as these subsidies make the use of remote lands more profitable. Since livestock is an extensive activity, subsidies that encourage its development are likely to increase forest conversion pressures (Kaimowitz 1996). If agricultural land is abundant, agricultural subsidies are unlikely to create a very intense pressure on forests.

From most perspectives agricultural intensification policies contribute to saving forests because they reduce the pressure for more land. But this is not always the case. Even subsidies that lead to the intensification of agriculture may indirectly provoke forest decline. For example, Southgate (1992) notes that, due to generous government incentives, agricultural intensification and land prices in southern Brazil rose rapidly during the 1970s and 1980s. Incentive policies encouraged land ownership concentration and the adoption of capitalintensive methods of production. Unfortunately, all of this resulted in increased rural unemployment. Some of the workers displaced by mechanisation and the concentration of land ownership migrated to forested frontier areas in the Amazon. Agricultural intensification policies thus led to more forest decline at that location.

Similarly, the introduction of mechanised soybean production led to major increases in forest clearing not only in the Cerrados of Brazil, but also Santa Cruz in Bolivia and parts of Paraguay (Angelsen and Kaimowitz 1998). This negative effect on forests is more pronounced when it is easier to substitute machines for labour. The same reasoning applies if the subsidies facilitate the use of other inputs, not just machinery, that substitute for labour. The introduction of pesticides and new varieties on the Pacific Coast of Nicaragua during the 1960s and $70 \mathrm{~s}$, facilitated the expansion of large-scale cotton production. As a consequence, scores of small farmers who lacked the ability to access these technologies had to migrate to forested areas.

\section{Policies that led to unmanageable international debt}

Various governments that unwisely allowed the rapid accumulation of international debt later became saddled with an unwieldy financial burden. It is easy to imagine that the pressure to earn foreign exchange and repay debts may force governments to quickly exploit forest resources for export. However, research does not support an unequivocal relationship between external indebtedness and forest decline. Kahn and McDonald (1995) examined the debt and deforestation link in 68 countries over the period 1981-1985 and concluded that debt service had a significant role in deforestation. But research by Capistrano and Kiker (1995), using data for 45 countries over the 1967-1985 period, reached the opposite conclusion. Methodological differences between the two studies may partly explain these contradictory results. 
It is interesting to note that if large international foreign exchange outflows to service debt obligations lead to deforestation, then it makes intuitive sense that countries that experience the opposite situation - a sudden and substantial increase of foreign exchange - should show a decrease in deforestation rates. However, studies of the situation in Ecuador covering the period before, during and after the petroleum export boom of the 1970s suggest that large inflows of foreign exchange did not diminish forest decline and that, in fact, they may have accelerated it (Wunder 1997).

Definitive evidence to derive conclusions of general validity concerning the links between foreign debt and overall forest decline is not available. However, when convincing scientific evidence is lacking, the opinion of top decision makers in forest-rich countries be relevant. In this respect, the words of the late Mr Cheddi Jagan, ex-President of Guyana, are significant:

The Guyana Shield countries carry heavy foreign debt loads. While it is difficult to prove a causal link between foreign debt and tropical deforestation in all cases, in Guyana, the dynamics of political and development decision-making do suggest a strong relationship. Similar patterns are also evident in the neighbouring region (World Commission 1997).

\section{Structural adjustment policies}

In their efforts to promote economic growth, many countries implement structural adjustment policies (SAPs). Encouraged by international financial assistance institutions, the main elements of these policies (World Bank 1990) are:

- correction of fiscal imbalances mainly through reductions in public expenditure;

- reduction of the role of the state in managing the economy;

- promotion of privatisation;

- removal of obstacles to international capital flows and to the formation and expansion of national capital markets;

- liberalisation of exchange policies;

- removal of restrictive trade policies; and

- deregulation of labour markets.

The environmental effects of these policies is a subject of much debate, mainly because there is not much definitive evidence. In some cases, these SAPs may unintentionally encourage forest decline by:

- inducing unemployment and greater poverty leading to substantial migration to forest areas;
- stimulating agricultural exports at the expense of forested lands; and

- stimulating forest exports based on unsustainable methods.

Neither do SAPs address the fundamental issues of inequitable economic and political power patterns that initially may have led to forest decline. These policies tend to be implemented in ways that do not hurt the powerful. Therefore, if the powerful are part of the problem, SAPs will be weak weapons in the solution to inequalities. On the contrary, they tend to favour the most economically adept that can effectively take advantage of the changing conditions introduced by the new policies. If SAPs favour wealth concentration, many of the dispossessed may be more inclined to pursue survival strategies based on consumption of public forest resources.

On the other hand, in many cases in tropical countries, SAPs are a necessary condition of economic growth. And economic growth eventually tends to lead to improved forest management and to less deforestation. The longterm net balance between these forces is far from clear. This net effect is also clouded by the rather undisciplined way in which SAPs are implemented.

It is interesting to note that one of the main advocates of SAPs, the World Bank, states that "the expansionary impacts of currency devaluations, tariff liberalization and reduction of real interest rates may be most directly and adversely felt in the natural resource use, especially in the forestry and fishery sectors" (1994b). But the Bank argues that these negative effects on forest resources are to a great extent due to the fact that governments fail to implement mutually supporting policies. Timing and sequencing generally deviate from the original SAP prescriptions. For example, price corrections are not accompanied by necessary policy and institutional reforms. Some undesirable public expenditure may be curtailed but other, equally undesirable, conditions are retained. Some perverse subsidies are eliminated while others continue to exist. This partial implementation of SAPs may turn the whole situation of forest resources for the worse.

Trade and foreign exchange liberalisation policies frequently improve the terms of trade for agriculture. If this happens, prices received by farmers increase, and so may deforestation when additional forest lands are diverted to agriculture. However, if there is a subsequent increase of agricultural wages, and particularly if the labour supply does not increase noticeably when higher wages are offered, the initial propensity to dedicate more 
lands to agriculture through deforestation may recede somewhat. Also, higher agricultural wages could conceivably increase demand for and scarcity of agricultural products, thus reinforcing initial agricultural price increases.

If liberalisation policies result in economic recession in the short term, as they sometimes do, urban food demand could well decrease and so could agricultural prices. Furthermore, there is some evidence that not all SAPs improve agricultural prices in the early stages. For example, many adjustment programmes in LatinAmerica resulted in the appreciation of exchange rates rather than in devaluation.

In detailed studies of the effects of SAPs in Bolivia, Cameroon and Indonesia, CIFOR found that devaluation had a variable effect, with the most intense pressures on forests taking place when competitive uses of land consisted of activities targeted at the export market. Also, government spending cutbacks generally did not greatly affect road construction, thus lending support to claims that SAPs are generally implemented in a piecemeal fashion rather than as coherently integrated programmes. Similarly, governments generally resisted the removal of major economic distortions. The exception was the contraction of government support to settlement programmes in Indonesia and Bolivia. Another was the elimination of agricultural input subsidies in Cameroon, but this appears to have led to accelerated forest decline in that country. In Bolivia, increased marginalisation resulting from the SAP did not create great pressure on the forest at the frontier as it would have been expected. (see Box 3). In Zambia, the elimination of fertiliser and transportation subsidies led to an expansion of shifting cultivation and deforestation (Holden 1997).

In the last few years, liberalisation policies as well as the globalisation of the world economy raised concern that unscrupulous and powerful transnational corporations that have a poor record of environmental or social management may take advantage of weak and cashstrapped forested countries and expand their unsustainable and resource degrading operations in these countries. Thus, in 1995, the World Resources Institute warned that concessions offered to Asian logging corporations in Surinam could lead to the country "losing its forests, and getting shattered biodiversity, ruined fisheries, eroded soil, displaced populations and perhaps ethnic strife in return”. Claude Martin, Director General of the World Wide Fund for Nature, indicated that "a disturbing new trend has emerged in Africa with an influx of Asian-based logging companies...In Cameroon a Malaysian timber firm is alleged to be involved in the
Box 3. Structural adjustment and the forests of Bolivia.

The SAP made tin miners poorer as the state-owned mining company laid-off 23,000 of its 30,000 workers and these had few alternative employment opportunities, if any. In addition many others whose livelihoods depended indirectly on mining activity were also poorer as result of the SAP. The SAP also apparently aggravated poverty in rural highlands, although evidence is inconclusive. In any case, migration from mining areas increased but most migrants went to cities rather than to the agricultural frontier. The relatively few migrants that did move to agricultural areas went to coca producing areas as small farmers in these areas had higher income and coca was a very labour-intensive crop. Other factors limited migration to non-coca producing areas. Public spending on settlement programs dried up. The amount of land granted to large farmers increased sharply. All this made it more difficult for potential migrants to get access to land. The SAP did not appear to have a substantial effect on lowland farmers. Mechanised rice production increased but this was probably at the expense of fallow areas rather than forests.

Large scale mechanised farming for soybean production did increase sharply as the removal of price controls on soybeans, devaluation, fiscal incentives for exporters, road construction and low export taxes more than compensated for the loss of credit and foreign exchange subsidies resulting from the application of the SAP. The net result was increased deforestation. Yearly forest clearing for large-scale agricultural production, mostly soybeans, expanded from 13,000 hectares in $1980-1985$ to 115,000 hectares in 1994 .

The SAP also led to increased timber exports from unmanaged forests that, as a consequence, where degraded. However logging companies built logging roads, which facilitated land clearing by small farmers.

The economic benefits generated by the expansion of soybean and timber production and exports may have outweighed their environmental costs but alternative policies could have reduced these costs and at the same time improved the distribution of benefits.

Source: Kaimowitz et al. (1997)

illegal export of more than 30,000 cubic meters of logs a month - bypassing official export controls by sending the wood out from a specially constructed harbour" (1996). In the past, overlogging by European companies destroyed the forests of the Côte d'Ivoire. Nigeria and the Congo and Cameroon are rapidly following suit.

These studies highlight the complexity of the various relationships involved in SAPs. As is the case with other causes of forest decline, it is difficult to draw conclusions of general validity. Impacts of SAPs are to a great extent country-specific, with a number of economic forces working in different, sometimes opposite, directions.

\section{Log export bans}

Governments frequently impose log export bans or prohibitive log export taxes to favour local industry and increase its competitiveness in world markets. By restricting market demand, log export bans or prohibitive 
$\log$ export taxes reduce domestic log prices and thus subsidise the domestic forest processing industry. Countries that have imposed such bans include among others, Brazil, Cameroon, Canada, Côte d'Ivoire, Gabon, Indonesia, Liberia, Malaysia, Papua New Guinea and the Philippines (Porter 1996).

Whether export bans and export taxes lead to forest decline or not is a subject of much debate. Again, the effects of these policies on forests depend on a number of complex factors. Under certain circumstances they could lead to forest decline. In other cases, conceivably to more sustainable forest practices.

Log export restrictions immediately reduce log demand and, consequently, the pressure to harvest forests. However, long-term impacts are less clear. Reduced demand translates into lower prices for logs. Where the export market previously absorbed a substantial part of national production, this price contraction can be important. When the price of logs is substantially depressed, the pressure to harvest forests surely must decline. However, the profitability of implementing sustainable forest practices would also decrease. In these circumstances, the relative convenience of converting forests to more profitable agriculture is likely to rise. This pressure to deforest will be more intense if agricultural lands are in short supply.

Because restricted logs are cheap, there is also less inclination on the part of the forest industry to use them efficiently. Log export restrictions can lead to industrial overcapacity and more inefficient forest industries. This was the case in Indonesia and Peninsular Malaysia (Constantino 1990; Vincent and Binkley 1992). Logging could become more careless and destructive, as avoiding damage to a less valuable forest may not justify the costs of improved logging technologies. Finally, lower forest profitability would diminish the propensity to invest in forest plantations.

If forest plantations were not covered by the ban, however, then the incentive to clear cut natural forests to establish plantations is higher, particularly if land is scarce.

Depending on the "elasticity" of these various reactions, trade restrictions may lead to higher levels of deforestation than liberalised trade. Without knowing the direction and magnitude of these relationships and chains of effects it is not possible to generalise about the aggregate impact of trade restrictions. Furthermore, and quite separate from the effects of log export bans on price and incentive systems, export prohibitions often result in illegal logging and exports. In some cases these policies spill over national borders. For example, the Cambodian log export ban resulted in illegal logging and exports to regional markets (Thailand, Vietnam).

Only country-specific studies can help to clarify the possible final effect of logging bans or other policies that restrict trade.

\section{Institutional factors}

\section{Policies that favour concentration of ownership}

In some countries, the concentration of land ownership is heightened by government policies that favour agricultural intensification, the export of large volumes of agricultural products, capital-intensive methods of production and access to credit.

In Latin America, the latifundia-minifundia complex has its roots in colonial times. While it may be argued that in some cases concentration of means of production may make economic sense in the short term, it also tends to generate less employment and to have extremely negative equity implications. Large numbers of farmers may be left without means of sustenance either because they lose their jobs or because they are compelled to sell their lands and other assets to larger and more competitive entrepreneurs. Many may move to forest areas. These effects can be so important that some governments have implemented reforms to provide land to displaced farmers. Since the redistribution of private productive agricultural lands is normally economically controversial and certainly extremely difficult from the political point of view, publicly owned lands (frequently under forest cover) are distributed by governments to landless farmers. Thus, voluntary or forced resettlement programmes have resulted in large areas of forest being cleared for subsistence agriculture.

Inequality of land ownership may also have other consequences. Dasgupta and Mäler (1994) call attention to the fact that increasing inequality often leads to the breakdown of common property management schemes.

\section{Land tenure policies}

In the past a generalised policy failure, that led to deforestation, was the requirement to demonstrate use of public lands to obtain legal property rights over those lands. A good way to demonstrate occupation and "improvements" of forest lands was to deforest. Furthermore, in many cases, deforested land is also better sheltered from expropriation by government policy. Land with forest cover may be declared as protected area and, if this happens, expropriation (or very drastic limitations 
to use forests for productive purposes) generally ensues. Thus, the simple declaration that government intended to expand the system of protected areas may have contributed to accelerating deforestation in Costa Rica (World Bank 1996). The growing realisation that these policies introduce important incentives to encourage deforestation led to policy reforms in many countries, particularly in Latin America, where the link between deforestation and land ownership is rapidly being erased by governments. ${ }^{5}$

If government policies do not recognise property rights, either formally or informally, and if there is little possibility to enforce recognised rights, then the propensity to abuse forest resources may increase. Weak property rights reduce the incentive to manage forests in sustainable ways. The World Bank 1991 Forest Policy states that weak property rights are behind deforestation and degradation in many areas. There is some evidence that this in fact so. Saxena (1988), in a study of Uttar Pradesh in India, shows that the effective enforcement of property rights is essential in explaining levels of forest decline. Southgate et al. (1989) have shown that land tenure security and deforestation are inversely related in a study of 20 cantons in Ecuador.

\section{Illegal activities and corruption}

Governments often cannot control illegal operations. This lack of control can be either deliberate (often corrupt) or determined by the limitations of administrative capacity. One way or the other, illegal use of forests is rampant in most forested countries. By their very nature, the true extent of illegal operations in the forestry sector cannot be known with precision, but evidence suggests that such activities are important and that they constitute an important underlying cause of forest decline. In the 1980s, the Philippines lost about US\$ 1.6 billion per year, a large share of the country's gross domestic product, to illegal logging. In 1993 Malaysian log exports to Japan were underdeclared by as much as $40 \%$. Up to one-third of the volume harvested in Ghana may be illegal and observers indicate that money injected into the country as part of a SAP led to illegal practices on a massive scale. Until recently, up to $95 \%$ of all logging in Indonesia was not entirely legal (Dudley et al. 1995). A wide range of illegal and corrupt acts can contribute to forest decline (see Box 4).

Many illegal operations are the consequence of corruption. Corruption can be defined as "the sale by government officials of government property for personal gain" (Schleifer and Vishney (1993), or
Box 4. A catalogue of illegal acts that promote deforestation and forest degradation.

Illegal logging

- Logging timber species protected by national and international law

- Contracting with local entrepreneurs to buy logs from protected areas outside the concession

- Logging outside concession boundaries

- Contracting with local forest owners to harvest on their land but then cutting trees from neighbouring public lands instead

- Logging in protected areas.

- Logging in prohibited areas such as steep slopes, riverbanks and water catchments

- Removing oversized or undersized trees

- Extracting more timber than authorised

- Logging in breach of other contractual obligations

- Obtaining timber concessions illegally

\section{Timber smuggling}

- Exporting tree species banned under international laws, such as the Convention on International Trade in Endangered Species of Fauna and Flora (CITES)

- Exporting illegal logs in contravention of national bans

- Exporting forest products in greater quantities than declared

Undergrading, undermeasuring and undervaluing timber, and misclassifying species

- Avoiding royalties and duties by declaring lower value and volume of timber than is actually extracted from timber concessions

- Declaring exports of lower-priced species instead of real higher-priced woods

- Overvaluing services provided by overseas businesses (sometimes subsidiaries) to artificially reduce profits in exporting country and to avoid corporate taxes

Source: based on Environmental Investigation Agency (1996)

"behaviour on the part of officials in the public sector, whether politicians or civil servants, in which they improperly and unlawfully enrich themselves, or those close to them, by the misuse of public power entrusted to them" (Transparency International 1996).

Illegal and corrupt operations are likely to have an important effect on forest management because they increase investment risks and thus reduce the propensity of investors to implement sustainable management programmes. Corruption weakens the administrative apparatus of the state as decisions begin to be biased against activities that do not attract bribes. The government is also deprived of income that could otherwise go to improving public administration. Corruption and illegal use of forests generate incentives for organising "cut and run" logging operations to the detriment of the quantity and quality of forest resources.

${ }^{5}$ It should be noted that the opposite holds in other countries. In India, absentee landowners frequently afforest their land to prevent illegal occupation. 
The forestry sectors of tropical countries are particularly susceptible to illegal operations and corruption, for several reasons.

- In most tropical countries, forest activities take place in remote areas, away from the press, the public and official scrutiny.

- Wood, particularly in tropical countries, is valuable but not inventoried. It is thus difficult to determine how much wood was illegally extracted.

- Frequently, officials have substantial discretionary power. High timber values and high discretionary power by poorly paid government officials are ideal conditions for corruption (ContrerasHermosilla 1997).

The linkages between illegal acts, corruption and forest decline have yet to be studied systematically. Global Witness (1998) described the scale of corrupt forest activities in Cambodia, and stated that in 1997 much of the estimated US\$ 184 million worth of timber felled in the country went into the pockets of corrupt officials. Illegal logging could mean the complete disappearance of Cambodia's forests in only five years. Friends of the Earth (1997) carried out intensive analyses of illegal logging and timber trade in four tropical countries (Brazil, Cameroon, Ghana and Paraguay). All these studies strongly suggest a close link between illegal and corrupt activities on one hand and forest decline on the other.

\section{Broader socio-economic underlying causes}

\section{Population growth and density}

One of the most frequently cited underlying causes of forest decline is population pressure. However the link remains controversial. Researchers have produced a large number of studies using various indicators such as population growth and rural population density but results are by no means conclusive.

That more population should translate into more deforestation and thus higher pressures to degrade forests makes intuitive sense. With increased population, there would be more families in search of land for agriculture or looking for fuelwood or timber. Larger numbers of people would also mean that more labourers would be available, forcing wages down and making activities that need labour, such as agriculture, more profitable. An effect in the same direction may occur if the demand for agricultural products expands because of the growing number of people who need to be fed. It is also interesting to note the hypothesis advanced by some analysts that forest degradation, deforestation and environmental deterioration in general, all resulting from increased population, may in certain cases result in further population growth. There are several reason for this vicious circle. For example, forest decline worsens the condition of the poor who depend on forest resources. In these circumstances, there may be more inclination to have large families to secure subsistence at old age. More children also provide a source of labour for the poor family. Thus a downward spiral of population growth, poverty, environmental deterioration and more population growth leading to more poverty, etc. can occur (Ekbom and Bojö 1999).

In fact, most studies generally indicate a positive relationship between population and deforestation. For example, researchers have shown that high rates of population growth led to environmental degradation in Sub-Saharan Africa. But most analysts are also very careful to indicate that there are many other factors that obscure this linkage. There may be forces that simultaneously affect both population density and forest cover, thus making it appear like one is the cause of the other when in fact it may not be. The present-day extent of forest in a country is the result of past deforestation and, unless reliable information on the evolution of forest cover is at hand, it is difficult to link forest cover today with population increases. At the local level, population density is the result of factors such as the availability of infrastructure, economic opportunities elsewhere in the economy, transportation and colonisation policies. Accordingly, population levels in these areas cannot always be considered as the "true" cause of forest decline. Along the same line of thinking, many authors note that loggers first make the forests accessible and then settlers occupy lands. If this is in fact the case, then population density is the result of logging and associated initial deforestation or forest degradation, not the other way around.

Similar inconclusive results exist in relation to other assumed effects of population expansion and density (see Box 5). While it is true that a larger population may increase the number of labourers, it is also true that many other factors intervene in making forest clearing for agriculture more or less profitable. The same comments apply to the link between population increases and expansion in demand for agricultural products and the propensity to deforest. Where additional demand can be satisfied using technologies that are labour-intensive and where abundant and accessible agricultural land may still exist, the effect on forests of a larger population is likely to be less important. Other factors such as income level and distribution, levels of urbanisation and technological change also influence the effect of population on forest cover and quality. If urban areas are able to absorb surplus labour and attract it away from forest zones, then forest decline is less likely to take place. Given the available evidence, there is no fundamental relationship between population growth or density that will necessarily always cause forest decline. 
Box 5. Population and Forest Cover in Indonesia.

A study by Sunderlin and Resosudarmo (1999) shows clearly the complexity of relationships involving a number of variables leading to forest decline in Indonesia, all of them acting in conjunction with population.

"Certain studies have claimed that population growth is the single most important variable explaining deforestation in Indonesia. After all, the population of Indonesia has grown from about 40 million in 1900 to 200 million in 1997. The area of agricultural land in Indonesia has grown steadily in relation to this population increase, resulting in substantial loss and degradation of the original natural forest cover. However, the population-centered explanation is distorted and misleading because it rests on a flawed and incomplete view of the role of population in deforestation. .....Population is best viewed as an intermediate variable affected by others, and not simply as an independent variable that acts alone in influencing the fate of forests.

We have seen that (a) a sharp decline in the rate of growth of rural population in certain provinces is not matched by an observable decline in the rate of deforestation and forest degradation; (b) people have moved to forest margin areas not only because of population pressure but also because of non population push factors such as conversion of agricultural lands and technological change in Java, and transmigration failures in the outer islands; (c) people move to forested areas not only because of push factors but also because of pull factors such as road construction, the infrastructural benefits offered through the formal transmigration program, and certain forms of attractive rural employment; (d) pressures on forests result not just from land clearing by rural landholders but also from increasing international and per capita domestic demand for the land under forests and for forest products; and (e) there are considerable pressures on forests that result from the indirect and direct effects of plantation development, mining and the logging sector."

\section{Economic growth}

Economic growth and expansion of income per capita result in growing demands for agricultural and forestderived products such as paper. As a result, expanding levels of income per capita would tend to accelerate forest decline. However, several authors argue that this relationship changes fundamentally as income per capita reaches certain levels and continues to grow after that. According to this hypothesis, at lower levels of income per capita, income growth would be associated with various forms of forest decline. When economies reach a certain threshold, the process is reversed. At this point, increases in the level of income per capita begin to be associated with factors such technological improvements, better functioning of government institutions, urbanisation and less relative dependence on agricultural and forest production. Achieving higher levels of income per capita leads to a fundamental change in the composition of demand for goods and services with greater demand for environmental services of forests and for uses, such as recreation, that do not necessarily lead to the loss of forest cover. This is the experience in the today's rich economies of the world.
Thus, income growth rates and their likely effects on forests should be related to the existing absolute level of income of the country or region in question. This relationship is represented by the "environmental Kuznets curve". There is some evidence that this curve exists in the forestry sector of developing countries (Vincent et al. 1997 and see Box 6). However, the empirical evidence for the existence of such a relationship is still too fragmented and weak to assume that it will hold across the tropical world. (There is the danger that some countries, perhaps many, will reach the income threshold too late, i.e. when most of the forest has already gone.)

Box 6. Economic growth and forest decline.

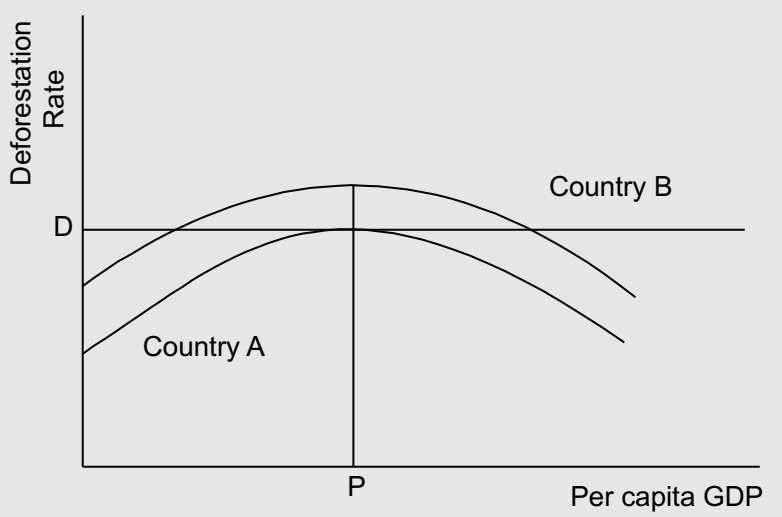

Cropper and Griffiths (1994) examined 64 countries and data series covering 28 years. They found some evidence of the environmental Kuznets curve for deforestation in Africa and Latin America. They estimated that the threshold where increasing per capita GDP no longer induces deforestation would occur in Latin America at about US $\$ 4,800$, while in Africa it would be around US $\$ 5,400$. In Africa, as compared with Latin America, increased population density shifts this curve upwards. If we assume two countries, $A$ and $B$, with similar resources but with Country $B$ having a higher population density, Country B needs to reach a higher level of income per capita before its rate of deforestation will return to level $D$. At a given income per capita level (say $P$ ) the rate of deforestation in Country B will be higher than in Country A (Griffiths 1994).

Panayotou (1995) studied this relationship for a group of developed and developing countries and found that it was valid, with thresholds occurring at about US\$1,200.

Vincent et al. (1997) studied detailed data at the district level from Peninsular Malaysia and found that the rate of deforestation was significantly related to the level of income per capita and supported the hypothetical inverted $U$ shape above, with deforestation rates peaking at some 1,100 Malaysian Ringgit (1978 prices). This level of income per capita was exceeded by the time of the 1987 Household Income Survey. Thus the deforestation rate should have been declining in the Peninsula at the end of the 1990s. The authors conclude that Peninsular Malaysia should be one of the first regions in the tropics to reduce its deforestation rate to zero and that "economic development appears to be delivering the permanent forest area that forestry policies could not". 
Furthermore, it is interesting to note that countries may follow a different path if income per capita contracts as compared to when it expands. A low-income country with a growing economy, say country B, may lead to an expansion of deforestation as shown in Box 6, but if that economy and income per capita subsequently contract this may not necessarily imply a return to former lower levels of deforestation. Sunderlin and Pokam (1998), studying deforestation in Cameroon and the effects of the economic crisis in the mid-1980s (the consequence of drastic declines in the prices of oil and agricultural crops, mainly coffee and cocoa), concluded that the contraction of income per capita did not reduce deforestation but instead led to an increase (see Box 7).

\section{Box 7. The Environmental Kuznets Curve in Reverse:} Cameroon.

At the end of the 1970s and until the mid-1980s, Cameroon experienced rapid economic growth, which was mainly based on oil exports. The Gross Domestic Product grew $7 \%$ per year. Migration from villages to the cities to take advantage of new employment opportunities was explosive. The population of Yaoundé grew by $107 \%$ between 1976 and 1987 . Villages instead stagnated. Cocoa and coffee were the principal cash earners for farmers in the humid zone. The government provided input subsidies to farmers.

Starting in 1986, the economy collapsed because of a drastic worldwide decline in the prices of oil and agricultural products. The government curtailed agricultural subsidies and thus discouraged agricultural intensification, which in turn encouraged extensive land use. The production and export of cocoa and coffee declined precipitously beginning in 1989. Urban poverty jumped from $1 \%$ to $20 \%$ between 1983 and 1993 and unemployment quickly grew from $7.3 \%$ to $24.6 \%$.

The rate of forest clearing increased over the period 1986-1997, compared to 1977-1985. What were the main underlying factors? First, the population of the villages increased substantially during the economic crisis in response to immigration, slow rural to urban migration and net return migration. Farmers increasingly turned to the production of food crops but largely kept their coffee and cocoa plots despite the collapse in prices and declining subsidies. This would usually be seen as economically irrational behaviour, but Sunderlin and Pokam indicate that farmers were reluctant to dispose of their cocoa stands because they viewed regeneration and replanting as essential, and local customs established that inherited orchards should not be cut down. Moreover, farmers were willing to expand the area under cocoa production in order to compensate for the decline in prices. Thus, farmers tended to establish their food crops at the expense of forests. They also turned to plantain, which is generally established in cleared forest lands, as a source of cash.

Source: Sunderlin and Pokam (1998)
Impacts of higher incomes will depend on the types of products and services related to forests that are demanded, and the way this demand is fulfilled. If such growing demand is concentrated on forest products, or on products and services produced in other sectors that require the use of more forest land (more roads, food, houses made of wood, etc.), then the likely impact is more forest decline. If income growth leads to reduced population expansion and to demand for services of forests, such as recreation and better environmental quality, then there will most likely be a positive effect on forests. Similarly, as income rises there may be more imports of goods that, if produced domestically (e.g. meat), may damage forests. Migration from rural areas to expanding job opportunities in other non-rural sectors would also reduce pressure on the forests. It is difficult to establish a priori the possible effect of economic growth on forests because these effects will depend on existing levels of income, the "elasticity" of demand for various products and services as income grows, the availability of these products and services domestically, etc., which in turn all depend on other variables such as income and wealth inequality. Again, explanations attributing an overwhelming driving force to one variable such as income growth are too simplistic.

\section{Conclusions and policy implications}

It could be argued that, according to various value systems and specific situations, deforestation and forest degradation is not always undesirable as suggested by the abundant literature on the subject. For example, it is easy to conceive of situations where environmental losses may be more than compensated by economic gains and improved well-being of the poor. Or where economic losses are more than offset by the additional welfare obtained by conserving some of the global biodiversity values of forests and the possibility of securing an independent means of evolution for traditional indigenous societies. Here we are more concerned with the underlying causes of forms of inappropriate or wasteful deforestation and forest degradation. Those forms of forest decline that, from most perspectives, are undesirable.

Generally, it is very a complex combination of market failures, negative elements introduced by various policy and institutional failures, and some fundamental features of societies, such as the distribution of political and economic power and cultural factors, that lead to forest decline. Despite the inclination of many analysts to 
attribute undesirable forest decline to a "dominant" factor such as trade or population growth, it is far more plausible that forest decline is the result of an elaborate "cocktail" incorporating different proportions of various causes.

The number and complexity of underlying causes of forest decline calls for caution. It is not possible to find unambiguous cause-effect linkages that would have a universal application. Rather, specific situations must be studied in detail and remedies must also be highly specific.

Despite all these cautions, there is enough knowledge to identify certain causes that, in most cases, are likely to have an influence on the quantity and quality of forests. First, we know that even if market failures may not be the main underlying causes of forest decline in all cases, if it were possible to "internalise externalities" and "get prices right" this would contribute to increased private inducements to sustainable forest management. These strategies may not provide the complete solution to the problem of undesirable forest decline, but they would clearly play a part in supporting better forest management and conservation.

We also know that whatever the original cause - close or distant - that motivates some government policies, many of them lead to wasteful forest decline. Much too often they exacerbate market failures. ${ }^{6}$ Road construction policies and policies to facilitate the expansion of railways and water transportation, if not properly filtered for their potential impacts on forests, are likely to induce deforestation and forest degradation by increasing accessibility. This effect will be more intense in situations where depressed agricultural conditions predominate and few other employment or survival options exist for poor populations. Thus, policies that lead to greater land tenure inequality and make the poor even poorer would likely compound the overall effect of misguided transportation policies. Since road construction policies generally are greatly influenced by political considerations, increased public scrutiny and more rigorous consideration of economic, environmental and social costs would help to concentrate road investments were they are most economically productive and least harmful to forests and forest-dependent populations.

Governments need to break the officially sanctioned connection between deforestation and the possibility of securing land ownership rights. This would go a long way towards reducing incentives for land speculation and forest decline. Fortunately, the negative consequences of this policy failure are now better understood and some governments, particularly in Latin America, have made substantial progress towards eliminating these policies.
Not only have they have erased previous policies that linked deforestation to ownership rights but some have even reversed these policies and now demand that a certain proportion of lands received from government be kept under forest. Some of the new policies also deny property rights to those who inappropriately deforested after the approval of the reformed laws.

Similarly, policies that favour mining and other extractive activities in forested areas will more than likely spur forest decline. Some of these activities, such as those of illegal gold miners in forested areas of Venezuela and Brazil, are extremely destructive to the environment, affecting not only the very existence of forests but also the quality of soil and water resources and the survival of indigenous populations. When extractive activities, such as oil exploitation in forested areas, generate large economic gains (e.g. Ecuador and Venezuela), it could be argued that a second round of effects may lead to an abatement of forest decline. More employment opportunities may be created in increasingly wealthy urban areas, demand for environmental services increased, and a proportion of the needs satisfied by importing products rather than by using national resources more intensively. Policies to foster activities such as mining and oil exploitation development in forest areas could thus be justified in the long run. However, evidence on the direction and intensity of these effects is less than definitive. In fact, the study of the experience in Ecuador suggests the opposite. This illustrates the concept that cause-effect policy relationships are particularly complex and difficult to analyse, particularly if we consider long time spans and various rounds of effects over time.

In most situations, the elimination of subsidies embodied in timber concessions, and those aimed at the promotion of activities that compete for forest land or that use forest raw materials in wasteful ways, may introduce additional incentives to improve forest management. They may restrict excessive forest harvest and, at the same time, produce additional government income, some of which may be directed to cash-starved forest services and used to promote sustainable forest management practices. A better analysis of the probable impacts of these government subsidy policies and increased transparency in public decision making are likely to lead to strategies that enhance incentives to more sustainable forest management. Because policy reforms in these cases are politically difficult, concerned advocacy groups and NGOs have an important role to

\footnotetext{
${ }^{6}$ For an excellent summary of the state of knowledge, see Kaimowitz and Angelsen (1999).
} 
play in attracting public attention to the documented negative effects of faulty policies.

As we have seen, structural adjustment programmes involve a large number of varied interventions, and thus create a rather large quantity of complex chain reactions in the economy. Some of these may lead to increasing short-term forest decline, while others may produce the opposite effect. Long-term net effects are uncertain. For example, if SAPs favour agricultural intensification by creating incentives to technological improvement and at the same time promoting off-farm employment and sustained income growth, the long-term effects are likely to lead to a reduction in the pressure on forests. If devaluation results in additional profitability for agriculture and land is scarce, the opposite may happen. However, if devaluation favours export agriculture, some of which requires agricultural intensification rather than extensification, the pressure on forests may decline. Experience shows that governments frequently implement SAPs in a piecemeal fashion, rather than as integrated and coherent economic packages. SAPs also favour export of tradable goods and often do not include environmental or social safeguards. These policies may exacerbate forces that lead to forest decline. There are no easy recipes to attenuate the potential negative shortterm effects of SAPs. Mitigating policies to include environmental and social concerns in the programmes have not been implemented with the necessary vigour and thus tend to have been rather ineffective. The longterm effects of SAPs on forests remain uncertain.

Available evidence shows convincingly that illegal and corrupt activities constitute a major underlying cause of forest decline. Solutions to this problem are complex and in most cases would involve a rearrangement of the forces dominating the political and economic scene. Without going to this extreme, all initiatives that make illegal and corrupt activities more visible help to combat inappropriate deforestation and forest degradation. Some influential international organisations, such as the World Bank Group, have adopted measures to increase transparency, monitoring and reporting of procurement contracts. Complementary measures may include the development of open bidding processes in timber concessions, methods to rank bids according to clear and pre-established criteria, measures to force the clear and unambiguous conditions of government procurement and timber concession contracts.

Depending on the circumstances, population may be important in deforestation and forest degradation processes but other related factors, such as income distribution and prices, may count more, at least in the short or medium term. Because population affects many other aspects of a country's socioeconomic situation, it is most unlikely that governments would give much weight to their specific impacts on forests. Other political and social considerations are liable to count more heavily in decision making.

The link between income growth and forest decline is far from clear except that at the existing levels of per capita income in most tropical countries, economic expansion is likely to lead to immediate further deforestation and forest degradation. In the long term, it is more probable that the relationship may be the inverse, as demonstrated by the experience of today's economically advanced countries. Whatever the case, as with the issue of population, it is unlikely that governments will give great consideration to forest sector issues in decisions about economic growth. 


\section{Bibliography}

Angelsen, A. and Kaimowitz, D. 1998. When does technological change in agriculture promote deforestation? Paper presented at the AAEA International Conference on Agricultural Intensification, Economic Development and the Environment, Salt Lake City, Utah.

Bryant, D., Nielsen, D. and Tingley, I. 1997. The last frontier forests: Ecosystems and economics on the edge. World Resources Institute, Washington, D.C.

Capistrano, A.D. and Kiker, C.F. 1995. Macro-scale economic influences on tropical forest depletion. Ecological Economics 14: 21-30.

Centeno, J.C. 1995. Forest concession policy in Venezuela. Paper for the World Resources Institute, Washington, D.C.

Collins, R. 1993. Information presented at the Seminar on Economic Aspects of Forest Revenues, Jakarta, Indonesia.

Constantino, L. 1990. On the efficiency of Indonesia's sawmilling and plymilling industries. Indonesian Ministry of Forestry and Food and Agriculture Organization, Jakarta, Indonesia.

Contreras-Hermosilla, A. 1997. The cut and run course of corruption in the forestry sector. Journal of Forestry 95(12): 33-36.

Contreras-Hermosilla, A. 1998. Pricing forest concessions. Paper for the "State of the world's forests" study. FAO, Rome, Italy.

Cropper, M. and Griffiths, C. 1994. The interaction of population growth and environmental quality. American Economic Review: Papers and Proceedings 84: $250-4$.

Dasgupta, P. and Mäler, K.G. 1994. Poverty, institutions and the environmental resource base. World Bank, Washington, D.C.

Dudley, N., Jeanrenaud, J.P. and Sullivan, F. 1995. Bad harvest? The timber trade and the degradation of the world's forests. Earthscan, London, UK.

Ekbom, A. and Bojö, J. 1999. Poverty and environment: Evidence of links and integration in the country assistance strategy process. Environment Group, Africa Region, World Bank, Washington, D.C.

Environmental Investigation Agency. 1996. Corporate power, corruption and the destruction of the world's forests. Earthscan, London, UK.
FAO. 1994. Forest resources assessment. Non-tropical developing countries. Mediterranean region. Report FO:MISC/94/3, Rome, Italy.

FAO. 1998. Forest resources assessment program. Working Paper 1, Rome, Italy.

FAO. 1997. The state of the world's forests. Rome, Italy.

Friends of the Earth. 1997. Cut and run. Illegal logging and trade in four tropical countries. Friends of the Earth International, Amsterdam, The Netherlands.

Global Witness. 1998. Going places.... Cambodia's future on the move. http://www.oneworld.org/ globalwitness/reports/GoingPlaces.htm.

Global Witness. 1997. Just deserts for Cambodia? Deforestation and the Co-Prime Ministers' legacy to the country. Briefing Document, London, UK.

Gray, J.A. 1997 Forest concession policies and sustainable management of tropical forests. Paper presented at the FBDS-FINEP-IBAMA-UNDP Workshop on Forest Policies and Sustainable Development in the Amazon, 14-16 July, Rio de Janeiro, Brazil.

Gray, J.A. and Hagerby, L. 1997. Forest concessions in Nicaragua: Policies and pricing. Administracion Forestal Estatal, Ministerio del Ambiente y Recursos Naturales, Managua, Nicaragua.

Griffiths, C. 1994. The environmental Kuznets curve. Examining economic growth and environmental degradation. Environment Dissemination Notes, Environmentally Sustainable Development Vice Presidency. World Bank, Washington D.C.

Gronow, J. 1996. Impact of recent FD/MLF policy measures: Log production and revenue. ODA Internal Memo, quoted by Day, B. (ed.) Who is collecting the rent? Taxation and super profits in the forest sector. Paper prepared for the World Bank, CSERGE, London, 1998.

Grut, M., Gray, J.A., and Egli, N. 1991. Forest pricing and concession policies: Managing the high forests of West and Central Africa. World Bank Technical Paper 143, Africa Technical Department Series, Washington D.C.

Holden, S. 1997. Adjustment policies, peasant household resource allocation and deforestation in northern Zambia: An overview and some policy conclusions. 
Forum for Development Studies, No. 1, Norwegian Institute of International Affairs, Flekkerfjord, Norway.

Kahn, J.R. and McDonald, J.A. 1995. Third world debt and tropical deforestation. Ecological Economics 12: 107-124.

Kaimowitz, D. 1996. Livestock and deforestation in Central America in the 1980s and 1990s: A policy perspective. CIFOR Occasional Paper No. 12, Bogor, Indonesia.

Kaimowitz, D. 1997. Factors determining low deforestation: the Bolivian Amazon. Ambio 26: 53740.

Kaimowitz, D. and Angelsen, A. 1998. Economic models of tropical deforestation. A review. CIFOR, Bogor, Indonesia.

Kaimowitz, D. and Angelsen, A. 1999. The World Bank and non-forest policies that affect forests. $\mathrm{http}: / /$ wbln0018.worldbank.org/essd/forestpol-e.nsf/ HiddenDocView/C53FED374902FE588525677C0 06A4084?OpenDocument

Kaimowitz, D., Byron, N. and Sunderlin, W. no date. Public policies to reduce inappropriate tropical deforestation. Unpublished manuscript.

Kaimowitz, D., Thiele, G. and Pacheco, P. 1997. The effects of structural adjustment on deforestation and forest degradation in lowland Bolivia. CIFOR, Bogor, Indonesia.

Kartodiharjo, H. and Supriono, A. 2000. The impact of sectoral development on natural forest conversion and degradation: The case of timber and tree crop plantations in Indonesia. CIFOR Occasional Paper No.26, Bogor, Indonesia.

Mahar, D. and Schneider, R. 1994. Incentives for tropical deforestation: Some examples from LatinAmerica. In: Brown, K. and Pearce, D. (eds.) The causes of tropical deforestation, 159-71. UCL Press, London, U.K.

Martin, C. 1996. From the Director General: Transnational loggers threaten Africa's forests. World Wide Fund for Nature, http://www.panda.org.

MineWatch. 1997. Mining and oil exploration. Document submitted to the Latin American and the Caribbean Public hearing of the World Commission on Forests and Sustainable Development, San Jose, Costa Rica.

Miranda, M. with Blanco-Uribe, A.Q., Hernandez, L., Ochoa, J. and Yerena, E. 1998. All that glitters is not gold. Balancing conservation and development in Venezuela's frontier forests. World Resources Institute, Washington, D.C.
Motta, M. 1992. Regimen de aprovechamiento del bosdque natural y sistema de tasas forestales. PNUD/ DNP, Santa Fe de Bogota, Colombia.

Munasinghe, M. and Cruz, W. 1994. Economy-wide policies and the environment. Environmental Paper 10, Environment Department, World Bank, Washington, D.C.

Myers, N. and Kent, J. 1997. Quoting A. Fraser in Perverse subsidies, their nature, scale and impacts. Report to the MacArthur Foundation.

Ostrom, E. 1990. Governing the commons: The evolution of institutions for collective action. Cambridge University Press, New York.

Panayotou, T. 1995. Environmental degradation at different stages of economic development.In: Ahmed, I. and Doeleman, J.A. (eds.) Beyond Rio: The environmental crisis and sustainable livelihoods in the Third World. Macmillan Press Ltd. London, UK.

Pearce, D. 1995. Blueprint 4. Capturing global environmental values. Earthscan, London, UK.

Pearce, D. and Warford, J. 1993. World without end. Economics, environment and sustainable development. Oxford University Press, New York.

Porter, G. 1996. Trade distorting policies and forests: An analysis and proposal for an IPF recommendation. Environmental and Energy Study Institute, Washington, D.C.

Repetto, R. 1993. Government policies, economics and the forest sector. In: Ramakrishna, K. and Woodwell, G. (eds.) World forests for the future. Yale University Press, New Haven, Connecticut.

Repetto, R. and Gillis, M. 1988. Public policies and the misuse of forest resources. Cambridge University Press, Cambridge, UK and New York.

Saxena, N.C. 1988. Social forestry in U.P. Hills. International Centre for Integrated Mountain Development, ICIMOD, Kathmandu, Nepal.

Sayer, J.A., and Byron, R.N. 1996. Technological advance and the conservation of forest resources. Journal of World Ecology and Sustainable Development 3(3): 43-53.

Schneider, R. 1995. Government and the economy on the Amazon frontier. World Bank, Washington, D.C.

Shleifer, A. and Vishney, R.W. 1993. Corruption. Quarterly Journal of Economics 108: 599-617.

Southgate, D. 1992. Policies contributing to agricultural colonisation of Latin America's tropical forests. In: Sharma, N. (ed.) Managing the world's forests: looking for balance between conservation and development . Kendall/Hull Publishing Company, Dubuque, Iowa. 
Southgate, D., Sierra, R. and Brown, L. 1989. The causes of tropical deforestation in Ecuador: A statistical analysis. London Environmental Economics Centre (LEEC) Paper 89, London, U.K.

Sunderlin, W.D. and Pokam, J. 1998. Economic crisis and forest cover change in Cameroon: The roles of migration, crop diversification and gender division of labour. Unpublished manuscript, CIFOR, Bogor, Indonesia.

Sunderlin, W.D. and Resosudarmo, I.A.P. 1996. Rate and causes of deforestation in Indonesia: Towards a resolution of the ambiguities. CIFOR Occasional Paper No. 9, Bogor, Indonesia.

Sunderlin, W.D. and Resosudarmo, I.A.P. 1999. The effect of population and migration on forest cover in Indonesia. Journal of Environment and Development 8: $152-69$.

World Bank. 1990. Adjustment lending: Policies for sustainable growth. Washington, D.C.

World Bank. 1994. Economy-wide policies and the environment. Washington, D.C.

World Bank. 1996. Natural resources management project. Draft notes, Washington, D.C.

Transparency International. 1996. Natural integrity systems: The TI sourcebook. Berlin, Germany.

Vincent, J.R. 1991. Unpublished analysis conducted for the World Bank, quoted in Vincent, J.R., Rozali Mohamed Ali and Associates (1997) Environment and development in a resource-rich economy. Malaysia under the New Economic Policy. HIID Institute of Strategic and International Studies, Harvard University Press, Cambridge, Massachusetts.

Vincent, J.R. and Binkley, C. 1992. Forest-based industrialization: A dynamic perspective. In: Sharma, N (ed.) Managing the world's forests: looking for balance between conservation and development . Kendall/Hull Publishing Company, Dubuque, Iowa.

Vincent, J.R., Awang Noor Abd. Ghani and Yusuf Hadi. 1993. Economics of timber fees and logging in tropical forest concessions. Unpublished Manuscript, Harvard Institute for International Development, quoted in Vincent, J.R., Rozali Mohamed Ali and Associates (1997) Environment and development in a resource-rich economy. Malaysia under the New Economic Policy. HIID Institute of Strategic and International Studies, Harvard University Press, Cambridge, Massachusetts.

Vincent, J.R., Rozali Mohamed Ali and Associates. 1997. Environment and development in a resource-rich economy. Malaysia under the New Economic Policy. HIID Institute of Strategic and International Studies, Harvard University Press, Cambridge, Massachusetts.

Wilkinson, B. 1998. Guyana - Environment: Government on the defensive on forest concessions. Inter Press Service, www.oneworld.org/ips2/apr/ guyana.html.

World Bank. 1990. Adjustment lending: Policies for sustainable growth. Washington, D.C.

World Bank. 1991. The forest sector: A World Bank policy paper. Washington, D.C.

World Bank. 1994a. Indonesia: Environment and development. The World Bank, Washington, D.C., as quoted by Sunderlin, W.D. and Resosudarmo, I.A.P. (1996) Rate and causes of deforestation in Indonesia: Towards a resolution of the ambiguities. CIFOR Occasional Paper No. 9, Bogor, Indonesia,.

World Bank. 1994b. Economy-wide policies and the environment. Washington, D.C.

World Bank. 1996. Natural resources management project. Draft notes, Washington, D.C.

World Bank. 1997. The evolution of Cameroon's new forestry, legal, regulatory and taxation system. Manuscript, Central and Indian Ocean Department, Washington, D.C.

World Commission on Forests and Sustainable Development. 1997. The causes of forest decline. Background Paper 8, Geneva, Switzerland.

Wunder, S. 1997. From Dutch disease to deforestation - A macroeconomic link? A case study from Ecuador. Working Paper 97.6, Center for Development Research, Copenhagen, Denmark. 